\title{
ESTRATÉGIAS DE PRODUÇÃO DE SI E DE BIOTECNOLOGIAS
}

\author{
Anita Guazzelli Bernardes \\ Neuza Guareschi
}

RESUMO. Este artigo problematiza a relação das biotecnologias com a produção de subjetividades na contemporaneidade, colocando em discussão a naturalização da evolução da espécie humana e da ciência que objetiva tomar as biotecnologias como um exemplo de progresso da humanidade neste momento atual da sociedade. Entendem-se as biotecnologias como condições de existência no contemporâneo e como biopolíticas que forjam modos de subjetivação, produzem sujeitos-forma, e não substância, em decorrência de atitudes experimentais que as transformam em uma condição humana. Diante disso, visa-se a tomar essa objetivação das biotecnologias e pensá-la como modos de viver constituídos no campo da saúde por meio de estratégias de produção de si, ou seja, de formas de subjetivação. Para isso, parte-se das concepções foucaultianas de poder, discurso, regimes de verdade e tecnologias de si, articuladas, principalmente, pelos debates de Bauman sobre a sociedade contemporânea e a discussão de Rose em relação às biotecnologias e governo do eu.

Palavras-chave: biotecnologia; produção de subjetividade; saúde.

\section{STRATEGIES OF SELF-PRODUCTION AND BIOTECHNOLOGIES}

\begin{abstract}
The relationship between biotechnologies and the current production of subjectivities is provided. Research discusses the naturalization of human evolution and the development of science in which Biotechnologies are taken as an example of humanity's advance within contemporary society. Biotechnologies are understood as current existence conditions and as bio-politics that mold various instances of subjectivity and produce subjects-forms instead of subjects-substance from experimental actions which turn them into human conditions. The objectification of Biotechnologies is approached as a way of living within the field of health by strategies of production of the self, or rather, as forms of subjectivity. The point of departure involves Foucauldian concepts of power, discourse, truth regimes and technologies of self, subjected to debates by Bauman on contemporary society and to the discussion by Rose on biotechnologies and the control of self.
\end{abstract}

Key words: Biotechnology, production of subjectivity, health.

\section{ESTRATEGIAS DE PRODUCCIÓN DE SÍ Y DE BIOTECNOLOGÍAS}

RESUMEN. Este artigo discute la relación de las biotecnologías con la producción de subjetividades en la contemporaneidad, poniendo en discusión la naturalización de la evolución de la especie humana y de la ciencia que objetiva tomar las biotecnologías como un ejemplo de progreso de la humanidad en este momento actual de la sociedad. Se entienden las biotecnologías como condiciones de existencia en lo contemporáneo y como biopolíticas que forjan modos de subjetivación, producen sujetos-forma, y no sustancia, como derivación de actitudes experimentales que las transforman en una condición humana. Ante eso, se objetiva a tomar esa objetivación de las biotecnologías y pensarla como modus vivendi constituidos en el campo de la salud por medio de estrategias de producción de sí, es decir, de formas de subjetivación. Para eso, se parte desde las concepciones foucaultianas de poder, discurso, regímenes de verdad y tecnologías de sí, articuladas, principalmente, por los debates de Bauman sobre la sociedad contemporánea y la discusión de Rose en relación a las biotecnologías y gobierno del yo.

Palabras-clave: biotecnología, producción de subjetividad, salud.

* Psicóloga, Doutora em Psicologia pela PUCRS, docente da Universidade Regional Integrada do Alto Uruguai e das Missões Campus Frederico Westphalen.

\# Doutora pela University of Wisconsin. Professora/Pesquisadora do Programa de Pós-Graduação em Psicologia da PUCRS. Coordenadora do Grupo de Pesquisa: Estudos Culturais e Teorias Contemporâneas. 
Este artigo problematiza a relação das biotecnologias com a produção de subjetividades na contemporaneidade, colocando em discussão a naturalização da evolução da espécie humana e da ciência que objetiva tomar as biotecnologias como um exemplo de progresso da humanidade no momento atual da sociedade. A contemporaneidade é o lugar de onde é possível ver e falar, entendendo-se com isso que biotecnologias, como condições de existência no contemporâneo e como formas de o biopoder se exercer, forjam modos de subjetivação que produzem sujeitos-forma, e não substância, em decorrência de atitudes experimentais que os transformam em uma condição humana.

Diante disso, visa-se a tomar essa objetivação das biotecnologias e pensá-la como modos de viver constituídos no campo da saúde por meio de estratégias de produção de si, ou seja, de formas de subjetivação. Para isso, parte-se das concepções foucaultianas de biopoder, discurso, regimes de verdade e tecnologias de si, articuladas, principalmente, pelos debates de Bauman (2001) sobre a sociedade contemporânea e a discussão de Rose (2001) em relação às biotecnologias e governo do eu.

As biotecnologias são entendidas como tecnologias da vida que forjam determinadas maneiras de o indivíduo relacionar-se consigo mesmo, tornando-se objeto de si por meio de processos de biotecnologização - um "si-mesmo" edificado pela relação que se estabelece entre saúde, vida e tecnologias. Segundo Foucault (1990), a investigação sobre o modo como os indivíduos têm desenvolvido, em nossa cultura, diferentes saberes sobre si mesmos deve amparar-se na relação entre regimes de verdade e as tecnologias políticas que prescrevem modos de viver.

As biotecnologias são compreendidas como biopolíticas, ou seja, como estratégias de o poder se exercer sobre a vida. De acordo com Foucault (1999), as biopolíticas são formas do que o autor nomeia de biopoder. $\mathrm{O}$ biopoder emerge na modernidade e exercese por meio de políticas voltadas para a vida. Estas dividem-se em duas formas distintas, as quais não se excluem, pelo contrário, reforçam-se mutuamente: uma, denominada anatomopolítica, centra-se no corpo como máquina e encontra na utilização e docilização da força deste corpo trabalhador a possibilidade de integrá-lo ao sistema de produção de riqueza; a outra, denominada biopolítica da população, centra-se no corpo como espécie, um corpo reconhecido por seus processos biológicos - "a proliferação, os nascimentos e a mortalidade, o nível de saúde, a duração da vida, a longevidade" (Foucault, 1999, p. 131). Gerir a vida passa a ser um programa de Estado, não porque a vida se torne importante enquanto valor em si, e sim, porque passa a ser um fenômeno necessário para o progresso da Nação, na medida em que a vida é produtiva.

A modificação na estrutura de governo é uma transformação dos modos de administração da vida, do cotidiano. Segundo Foucault (2004, p. 302), "por intermédio de alguma tecnologia política dos indivíduos, fomos levados a nos reconhecermos como sociedade, como elemento de uma entidade social, como parte de uma nação ou de um Estado". Essas tecnologias políticas, criadas na modernidade, dedicam-se à proteção da vida, vida esta inscrita no indivíduo que deve ser integrado a essa entidade social. A maneira pela qual se forjou essa possibilidade foi marcar esse indivíduo tanto no sentido de ser um homem que vive, trabalha e fala, quanto no de estar ligado a uma entidade social, ou seja, pertencer a uma Nação, na medida em que faz parte da população desta.

De acordo com esse mesmo autor, as tecnologias são subdivididas em quatro tipos principais, embora não devam ser entendidas em seu funcionamento de modo separado: 1) tecnologias de produção, transformação e manipulação, que permitem ao indivíduo a experiência do artificialismo da existência humana; 2) tecnologias de sistemas de signos, que permitem pensar o indivíduo como sujeito da linguagem; 3) tecnologias de poder, que governam as condutas dos indivíduos, submetendo-os a certas finalidades e à dominação e tornando-os objetos; 4) tecnologias de si, que permitem ao indivíduo tornar-se objeto de si mesmo ao efetuar certo número de operações sobre seu corpo, sua alma, seus pensamentos, sua forma de ser, com a finalidade de transformar a si mesmo (Foucault, 1995).

Dessa forma, as tecnologias são formas de governo de si e do outro, são operações sobre os modos de viver, ou seja, sobre as possibilidades de vida. Essa compreensão implica a noção de que o sujeito não é substância, e sim ,forma. Essa forma essa não é para todo o sempre idêntica a si mesma, visto que, ao tornarse sujeito de uma determinada verdade, o indivíduo opera sobre si mesmo uma série de transformações no modo de viver e no seu corpo. Para Nietzsche (1998, p. 36), "não existe um tal substrato, não existe ser por trás do fazer, do atuar, do devir; o agente é uma ficção acrescentada à ação - a ação é tudo". As transformações tratam das relações que podem existir entre a constituição do sujeito, ou das diferentes formas de sujeito em jogos de poder, saber e verdade. 
Assim, este artigo pretende visibilizar que as tecnologias são edificações que tomam o corpo e a vida como objeto tecnocientífico, no intuito de transpor aquilo que tornou o humano objeto de conhecimento: a finitude. Nesse cenário, emerge a figura do pósorgânico, do pós-humano. Desse modo, as biotecnologias, como mecanismos biopolíticos, são estratégias de produção de subjetividades relacionadas a um conjunto de regras forjadas pelo campo da saúde que lhes permitem aparecer e ser tomadas como objetos de determinados discursos.

\section{BIOTECNOLOGIAS: INTERVENÇÕES TÉCNICAS NA VIDA}

As biotecnologias emergem a partir da década de 1950, quando, na esteira das transformações científicas, o material genético torna-se o substrato de pesquisas e intervenções no campo da ciência. A vida torna-se passível de intervenções técnicas - as biotécnicas. Dessa forma, as biopolíticas não agem mais apenas nos fenômenos de população - como natalidade, mortalidade, casamentos, habitação -, mas naquilo que passa a ser considerado como determinante das formas de viver: a biologia molecular. Nesse processo, configura-se um novo personagem desenhado artificialmente: o bióide. Diferentemente, então, do que propôs Darwin, os seres vivos passaram a não depender mais da seleção natural para tornarem-se diferentes do que eram. Por meio da ciência, torna-se possível alterar certas condições genéticas, criando uma forma de subjetivação sustentada na racionalidade de que "tornamo-nos mármore bruto para nosso próprio engenho e arte, nossos corpos e espíritos são doravante insumos que podem ser manipulados para o engendramento de novas corporalidades e novos seres" (Oliveira, 2004, p.1). Esse programa ${ }^{1}$ de intervenção técnica na vida constitui-se tanto da relação que se estabelece entre características genéticas e morfologia quanto de intervenções programadas em processos genéticos de inclusão, exclusão e substituição de genes precisos.

Com essas transformações no campo das ciências da vida, também ocorrem modificações no campo dos sistemas de informação, fundamentalmente na área da informática. Com a biologia molecular surge a possibilidade de composições interespécies; com a

Intitula-se de programa pois diz respeito a um projeto tecnocientífico relativo ao "desenvolvimento e progresso" das ciências da vida em correlação com as ciências da informação. engenharia da informação, surge a composição das espécies com as máquinas, ou seja, moléculas orgânicas com inorgânicas, naturais com artificiais.

Assim como nos deparamos com a existência de bióides, também encontramos a existência de figuras cibernéticas, ou os ciborgues. Ambas as formas são efeitos da hibridização de matérias diferentes por meio de biotecnologias. A modificação dá-se não apenas sobre os corpos e espíritos, mas também sobre a codificação do que é ser humano, sobre as fronteiras entre a vida e a morte. A tecnociência deixa de ter seu foco exclusivamente no exotismo macrofísico, voltado para o universo, e penetra no espaço íntimo do corpo humano, na colonização da microfísica do cotidiano. As biopolíticas investem na espécie humana no que ela tem de microfísico: na vida enquanto material biológico.

As biotecnologias vêm ganhando um espaço cada vez maior na produção de formas de pensar e relacionar-se consigo mesmo. Uma forma de captura de sujeitos que transpõe as fronteiras dos laboratórios é feita por meio da mídia, como estratégia micropolítica de colonização do cotidiano. A mídia ganha, na contemporaneidade, um espaço cada vez mais amplo de produção de sentidos e sujeitos por meio de tecnologias de controle, de biopolíticas. Desse modo, a mídia tornase um vetor de biotecnologização, na medida em que constrói os sentidos de como e quanto devemos experimentar e necessitar os avanços biotecnológicos, principalmente no que tange à saúde. Por meio de diferentes estratégias, ela coloca em discurso a relação saúde e biotecnologias de forma cada vez mais ostensiva, forjando os modos como devemos tanto conceituar a saúde quanto experimentá-la. As biopolíticas forjam esse território em que se relaciona saúde com biotecnologias, de modo que a vida passa a ser experimentada por meio da saúde e das biotecnologias. Um exemplo disso encontra-se na revista Istoé, impresso de circulação nacional, que conta com uma seção intitulada "Século 21: ciência, tecnologia e meio ambiente". Um de seus fascículos (Menconi \& Pinho, 2004) apresenta as incursões microfísicas da biologia molecular, considerando as imperfeições dos corpos um mal que deve ser combatido:

As abomináveis acnes podem estar com os dias contados. Cientistas alemães seqüenciaram o genoma da bactéria que vive dentro das glândulas que secretam óleo da pele. Entre os 2333 genes, foram identificados aqueles diretamente envolvidos na habilidade do micróbio de atacar e destruir a pele humana. A descoberta abre possibilidade para o desenvol- 
vimento de remédios mais eficazes para o mal que afeta quatro em cada cinco pessoas (p. 93).

As biotecnologias encontram-se na atualidade como condições de existência do humano; um humano que conforma sua existência em rituais de upgrade, em que o organismo não é mais um limite existencial, impondo-se a necessidade de transcender a própria condição humana. Nesse jogo, encontram-se vetores de subjetivação relacionados tanto à informação - pois, assim como a informática, o código genético também é considerado uma matriz de informações sobre o humano - quanto à colagem da vida na biologia. Não se trata de submeter o humano à máquina biológica e computacional, mas sim, de integrá-lo a elas, fazendo disso a condição de possibilidade da vida; ou seja, as máquinas não estão mais a serviço da vida, elas são a própria vida. A genética e a computação integradas com as biotecnologias não lidam com a perspectiva de captar um sujeito que estaria separado, um sujeito-alvo, e sim, um sujeito que só é possível por sua integração tecnológica em um processo de indiferenciação inclusiva. Nas palavras de Sibila (2002, p. 52): "Numa perspectiva perfeitamente alinhada com o paradigma digital, portanto, é a informação que constitui a essência do ser e irá determinar a confusa fronteira entre a vida e a morte".

Esse saber sobre a vida é atravessado por estratégias de controle sobre ela. O controle da vida reconfigura a morte e o envelhecimento. A morte, como diria Foucault (1999), que seria aquilo que escapa das relações de poder, o limite, a extremidade do poder, não é mais o limite para os jogos políticos, pois a tecnologia, por meio das biopolíticas do cotidiano, está tornando a morte obsoleta, já que o poder investe cada vez mais no fazer-viver, o qual não recai apenas sobre a vida como um fato, mas sobre os modos de viver. Não se trata apenas de escolhas, pois as possibilidades de escolha são efeitos das tecnologias a serviço da vida.

$\mathrm{Na}$ mesma seção da Istoé citada anteriormente (Menconi \& Pinho, 2004), encontra-se também uma reportagem sobre supercurativos. São tecidos desenvolvidos a partir da combinação de moléculas orgânicas e inorgânicas utilizando-se nanotecnologia ${ }^{2}$, os quais a princípio são voltados para atletas, na tentativa de evitar as intempéries do tempo, mas acabam por conter poderes curativos: "A grande novidade do tecido, porém, está em sua propriedade curativa. O segredo é a prata, um metal que age contra

2 A nanotecnologia trabalha com medidas mínimas, $100 \mathrm{mil}$ vezes menor que um fio de cabelo. a formação de bactérias, inibindo a respiração e reprodução desses microorganismos (...) Ela (prata) evita que os ferimentos infeccionem e interfiram no desempenho do atleta” (p. 91).

Desse modo, as "abomináveis acnes", tanto quanto os ferimentos que interferem no desempenho, na era das biotecnologias fazem parte de um corpo orgânico que se tornou o lugar do mal. Este deve ser superado como forma de ascender à saúde, o que não recai apenas sobre atletas, mas sobre qualquer condição de existência, desde as acnes que recobrem os rostos de adolescentes até programas de televisão cujo tema é a possibilidade de transformação total do corpo por meio de intervenções cirúrgicas para retardar ou evitar o envelhecimento. O livro Beleza sem cirurgia (Menconi \& Pinho, 2004) traz cuidados que podem adiar a plástica, ou seja, as cirurgias de rejuvenescimento já são consideradas como aquilo que efetivamente fará parte, mais dia, menos dia, do cotidiano das pessoas.

Quando tomada pelas biotecnologias, a saúde é imposta como necessária e torna-se objeto de consumo. Não se trata de qualquer saúde, mas da saúde que visa, para além do aperfeiçoamento orgânico, a sua transcendência. $\mathrm{O}$ orgânico que delimitava a existência humana cede lugar à informação, à tecnologização do corpo. Tendo-se acesso ao código genético, tudo mais é dispensável, quer dizer, é modificável. As biotecnologias, agenciadas por biopolíticas como o cuidado perene com a saúde, criaram a idéia de controle sobre os corpos, sobre as existências, agora sendo possível comprar e escolher os artefatos que melhor sirvam à vida. Em uma entrevista, Joana Prado ${ }^{3}$ refere que os seios de silicone que havia colocado eram seus porque os havia comprado. Saúde é artefato de consumo.

Comprar seios, assim como adquirir outros artefatos do campo da saúde, equaliza a vida com o capital, configurando jogos de força que se envergam sobre os sujeitos, tornando-os consumidores técnicos de saúde. Isso torna-se possível pelo investimento biopolítico, um poder que age sobre a vida e a torna objeto de consumo. De uma disciplinarização dos corpos que se adaptavam e se submetiam a regras, organizados em grandes meios de confinamentos, a capitalização da vida tornou possíveis jogos de controle perenes em que o sujeito é aquele que está sempre endividado, visto ser um consumidor. Desaparece a figura do operário e emerge a figura do

\footnotetext{
Personagem de um programa de televisão reconhecida por seus atributos físicos, em entrevista a um programa de televisão da rede Bandeirantes no ano de 2000.
} 
consumidor, como subjetividade do final do século XX.

Essa transformação de uma sociedade disciplinar em uma sociedade de controle marca distinções entre estratégias políticas (Deleuze, 1992). Em uma sociedade disciplinar, a vida organizava-se a partir de meios de confinamento, ou seja, tempo e espaço estavam correlacionados e dependentes, passava-se de um espaço-tempo para outro que já se encontrava predeterminado (família, escola, trabalho, aposentadoria, etc.) e as estratégias de poder voltavamse para o corpo enquanto anatomia. Em uma sociedade de controle, em que a vida se torna objeto de consumo e tecnologização, o tempo, seja ele de duração da vida ou mesmo de realização de uma determinada atividade, é marcado pela produção de mercado a partir de uma fragmentação da produção; quem passa a regular o tempo é a demanda de mercado, e o mercado agora é flexível e biotecnológico. As formas de viver transformam-se segundo a flexibilização do mercado: qualidade, autonomia, criatividade, versatilidade, polivalência, flexibilidade, empreendedorismo. Modificar o próprio corpo torna o indivíduo um empreendedor de si mesmo, um sujeito saudável. O empreendedorismo em relação à própria saúde torna-se uma tecnologia de si, uma forma de subjetivação. Trata-se de uma forma de organização social em que o sujeito é modulado como uma moldagem autodeformante que muda continuamente, a cada instante, por meio de biotecnologias e do consumo. Impõe-se, então, a necessidade de formação permanente tanto profissional quanto corporal.

Ao encontro dessas idéias, Pelbart (2000, p. 33) escreve: "O resultado é que a pós-modernidade comporta a presença do eixo consumidor/mercadoria em todos os pontos do espaço-tempo social. Tudo pode ser comprado, mesmo a vida (suas formas ainda inexistentes já são comercializadas no mercado da engenharia genética ${ }^{4}$ ), até o tempo". É uma forma de experimentação do tempo que cria uma abertura contínua no sentido de uma suposta liberdade, entendida como flexibilidade. $\mathrm{O}$ controle remete a trocas flutuantes sem delimitação espaçotemporal; a produção pode estar em qualquer lugar em qualquer momento, e ter saúde, ser saudável, é uma questão de mercado. Esses modos de viver dizem respeito a uma experimentação do tempo como puro presente. Nas sociedades de controle nunca se termina nada, estamos sempre devendo; criam-se continuamente novos métodos para tornar um indivíduo mais saudável,

4 Aqui é utilizado o termo engenharia genética e não biologia molecular por tratar-se de uma citação do autor. portanto, uma subjetividade empreendedora. A figura do consumidor/indivíduo/empreendedor não mais é reconhecida como cidadão, como parte de uma cidade, pois sua dignidade vem da possibilidade de acesso a bens de consumo e transformação de si por meio de tecnologias da vida; ou seja, é um sujeito que se dá a produzir integralmente. As tecnologias de si são encontradas por meio da prática esportiva, seja em academias seja mediante esportes mais radicais exercitados ao ar livre, a busca por cirurgias plásticas, a utilização de produtos dermatológicos e dietéticos light.

\section{BIOTECNOLOGIZAR-SE: ARTIFICIALISMO COMO CONDIÇÃO HUMANA}

As transformações de si por meio de biotecnologias que criam o sujeito empreendedor de si mesmo fazem-se mediante estratégias políticas. Foucault (1987,1999), em dois momentos distintos, escreve sobre as formas de governo do corpo. Em um primeiro estudo genealógico, intitulado "Vigiar e Punir", Foucault (1987) assinala a relação que as formas disciplinares de poder estabelecem com o corpo. O corpo na disciplina é um material moldável que exige uma tecnologia anatômica para melhor docilizálo. Os exemplos escolhidos para explicar essa forma de sujeição do corpo encontram-se no exército e nas escolas. A ênfase das práticas disciplinares situa-se na organização dos espaços, na regulação do tempo e dos movimentos, o que produz um esquadrinhamento dos corpos. A anatomia disciplinar separa o corpo em membros, órgãos e funções. As tecnologias de poder investem na anatomia corporal e produzem indivíduos, criando uma forma de anatomocorpo.

Em um segundo estudo genealógico, como na "Vontade de Saber", Foucault (1999) elabora a perspectiva de uma biopolítica; a relação com o corpo transforma-se, pois, quando o poder passa a focalizar a vida, o corpo torna-se matéria da vida. Ou seja, as biopolíticas voltam-se para os fenômenos da vida, e o corpo então passa a ser tomado como mais uma das formas de vida - passa a ser o território da saúde. $\mathrm{O}$ soma, ou o somatocorpo, é o corpo vivo: não se trata apenas de membros, órgãos e funções, mas daquilo que possibilita tornar-se objeto de conhecimento: a vida. As formas de exercício das biopolíticas referem-se às práticas destinadas ao controle das populações, um controle focalizado nas formas de vida, nos modos de viver. 
As biotecnologias são discutidas aqui nessa esteira tecnológica que se volta para o corpo como anatomia e como forma de vida. As biotecnologias, como tecnologias de si, não são o poder, mas os procedimentos mediante os quais as relações de poder são exercidas (Foucault, 2004). Essas tecnologias tratam de uma série de trabalhos efetuados pelo sujeito sobre o corpo que se estendem para além da epiderme, tanto no sentido de um "dentro" quanto no sentido de um "fora". Aliás, por meio das biotecnologias, criamse outras formas de compreensão de um interior e de um exterior. As biotecnologias voltam-se para a constituição de um dentro - por exemplo, o genoma, que seria a materialidade mais interior do sujeito, aquilo que torna possível a existência, que determina as formas de existir, forjadas de dentro para fora; ao mesmo tempo, voltam-se para um fora ${ }^{5}$, pois é na medida em que o fora se torna um limite para o dentro que este deve ser modificado. A vida não pode ser um limite para o vivido - o corpo tem que extrapolar as barreiras da finitude para atualizar-se como potência tecnocientífica.

Os procedimentos de si nas biotecnologias têm como foco o corpo, um corpo que se faz como tal por meio de uma série de trabalhos de disciplinamento e controle. As biotecnologias vão desde o aperfeiçoamento do corpo até sua transformação mediante a hibridização com outras materialidades, sejam elas orgânicas ou inorgânicas: os exercícios físicos constantes (as academias já são 24h), a alimentação balanceada (proteínas, carboidratos, vegetais, fibras), a manipulação do corpo (cirurgias plásticas, lipoaspiração, substância butolínica) tornamse práticas cotidianas. São técnicas corporais, visto que as substâncias das biotecnologias são encontradas no corpo, um corpo que é orgânico e vivo, pois o genoma é o que dá origem ao orgânico e à vida, tornando-os condições inseparáveis para os modos de viver. De acordo com Rose (2001), as técnicas corporais não são relativizadas pela diversidade cultural, em que cada

5 Levy (2003) faz uma discussão do conceito de Fora proposto por Blanchot (2001) e utilizado em alguns momentos por Deleuze e Foucault. O "fora", na conversa que a autora realiza com esses três pensadores, constitui mais uma experiência do que propriamente um lugar; encontra-se mais como um não-lugar. É mais próximo de uma função, de uma prática que se volta para a problematização de um fazer - um fazer que seria ele próprio fundador de sua realidade. Entretanto, aqui não se trata de operar com o conceito de "fora", mas de olhar o modo como as noções espaciais de dentro e fora são construídas, e não tomadas como uma realidade independente. grupo, comunidade ou nação produziria diferentes técnicas; essa diversidade diz respeito a diferentes regimes corporais que têm sido pensados e implementados como formas racionalizadas de produção de si.

As biotecnologias enaltecem a objetivação do humano como artificialismo da vida. São elas as formas nas quais a noção de que o humano pode agir sobre si mesmo recrudesce, tem autonomia para criar e transformar a própria forma de vida; ou seja, o humano pode forjar a vida. Elas potencializam o artificialismo da experiência humana não só no sentido da fabricação de artefatos - biotecnologias -, mas também no de tornarem o humano um artefato de si mesmo.

A fabricação de si por meio de biotecnologias está a serviço da vida, da qualidade de vida que deve ser consumida cotidianamente - é uma imposição ter saúde. É para a possibilidade de uma vida mais saudável que trabalham as biopolíticas. Não obstante, é importante assinalar que as biotecnologias não constituem o eixo final do "eu" como objeto transistórico devido ao progresso tecnocientífico. As biotecnologias são uma das formas forjadas na contemporaneidade por meio das quais os sujeitos compreendem a si mesmos e se relacionam consigo mesmos; são um dos efeitos das biopolíticas. A qualidade de vida é objetivada tanto pelos manuais de auto-ajuda, que implementam a noção de um autodesenvolvimento da consciência e da força do pensamento, quanto pela possibilidade de intervenção tecnocientífica na vida (Rose, 2001).

As intervenções tecnocientíficas voltam-se não para uma dimensão epistemológica, mas sim, para uma dimensão biológica de si. Essa dimensão biológica de si, esse eu biológico, não define mais o limite da existência, mas a possibilidade de manipulação das condições de existência. O eu como fato da vida é passível de transformação, pode agora transformar-se no que quiser, essa é a subjetividade no contemporâneo. A intervenção genética, assim como cria categorias de "eus" por meio dos traços estabelecidos geneticamente (personalidade, caráter, constituição física, predisposições, etc), inventa a possibilidade de agir sobre o fato da vida: o gene dá origem à vida, mas por meio do gene podem-se modificar as condições de vida. Cria-se a idéia de que agora é possível escolher o que se quer ser - o sujeito agora tem autonomia sobre si, como o sonho moderno tanto desejou..

O corpo, ao ser manipulado pelas tecnologias, acaba por ser recriado, pois é um corpo que deve ser suplantado em sua organicidade, e aquilo que se tornava condição de existência deve ser superado 
(Sibila, 2002). A vida biotecnologizada é mais do que a organicidade. Aliás, é justamente a organicidade do corpo que faz do sujeito um sujeito imperfeito e perecível. A saúde é poder manipular esse corpo imperfeito e perecível e transformá-lo em um corpo pós-orgânico - o eu ciborgue.

O corpo anatomossomático agora é um corpo genético, o eu é um eu genético. A genética tornou-se um vetor de subjetivação. A conformação genética do eu tem como projeto o indivíduo. Mesmo o código genético sendo igual em todos os seres humanos e pouco diferente do dos animais, a atualização e manipulação genética criam os indivíduos, os "eus" particulares, frutos de escolhas e intervenções. O ser humano transforma-se em ser genético, em ciborgue. Agora não se trata mais de tecnologias disciplinares de longo prazo, pois as tecnologias agem no gene. $\mathrm{O}$ ser humano destitui-se da responsabilidade de ser o que é, mas torna-se responsável por transformar aquilo que é (Sibila, 2002).

\section{NA CORDA BAMBA DA VIDA: ESTRATÉGIAS DE PRODUÇÃO DE SI}

A arte de governar ${ }^{6}$ das biotecnologias constitui-se como instrumento por meio do qual os indivíduos constituem a si mesmos, as relações que instituem consigo mesmos, as práticas nas quais os sujeitos conformam um "eu" pelo qual se reconhecem (Rose, 2001), um "eu" que, nesse caso, deve ser saudável. O argumento de Rose (2001) para sustentar essa discussão diz respeito a compreender que mudanças sociais tais como as biotecnologias "não transformam as formas do ser humano em virtude de alguma experiência que eles produzam" (p. 36), pois isso pressupõe que os seres humanos sejam sujeitos da história e estejam equipados para atribuir sentidos às suas experiências. $O$ que esse olhar sugere é que atribuir sentidos tem sua própria história. Então, as biotecnologias não são formas de os sujeitos atribuírem sentidos a uma certa experiência, visto que esses sistemas de verdades com códigos, regras, normas "não são produzidos pela experiência; eles produzem a experiência", eles produzem os sujeitos dessa experiência (Rose, 2001).

6 O conceito de governar segue a proposta de Foucault (1999) quando elabora suas discussões sobre as estratégias de poder, que dizem respeito tanto à relação de uma ação sobre outra ação possível - tecnologias de governo do outro - quanto à inflexão da ação sobre si mesmo tecnologias de si, tecnologias de governo de si.
As tecnologias não chegam prontas, mas estão perenemente sendo inventadas, lapidadas, implantadas de distintos modos, localizando os indivíduos em regimes de "eus" particulares: eu-corpo, eutrabalhador, eu-ciborgue, eu-comunidade, eu-normal, eu-anormal, eu-saudável. Não é uma história contínua e progressiva do "eu", mas de diferentes modos de pessoalizar a relação que o sujeito estabelece consigo mesmo, tornando-se seu próprio objeto. Trata-se de uma genealogia da subjetivação centrada não nos grandes eventos e mudanças históricas, mas nas micropolíticas do cotidiano da saúde, de biopolíticas cotidianas nas quais entra em jogo a relação do sujeito consigo mesmo por meio das biotecnologias.

As tecnologias da vida, no campo da saúde, além de transformarem o fato da vida em um modo de viver, criam estratégias de conformação de "eus". É um eu história de muitas vidas, é um eu corpo/saúde. As tecnologias são agenciamentos estruturados por uma racionalidade prática que, por meio de estratégias de governo, ou seja, por biopolíticas, toma os modos de ser humano como objeto, produzindo subjetividades que consomem biotecnologias como forma de controle do corpo e da vida.

A partir disso, algumas linhas colocam em jogo as biotecnologias: a vida, a saúde e as tecnologias de si. Vida, saúde e tecnologias são ao mesmo tempo objeto e efeito. São objeto quando emergem como aquilo que é possível ver e falar, como aquilo do qual devemos nos ocupar; são efeito enquanto aquilo que subjetiva, que produz uma certa experiência e modo de relação consigo mesmo. As biotecnologias objetivam certas formas de vida e de saúde, ao passo que produzem modos de experimentar a vida e a saúde por meio de tecnologias de si. É pelo modo de objetivação da vida colocada em correlação com a saúde que a existência contemporânea tenta controlá-la, como escreve Pelbart (2000, p.7): “....as acrobacias do mundo contemporâneo tentam dissimular a todo o custo: a percepção vertiginosa de que se está por um fio, a descoberta penosa de ver-se reduzido a quase nada, a suspeita crescente de que esse pouco talvez não baste para prosseguir".

A vida é então tomada como fato e como forma. Fato como objeto em si - a vida biológica e histórica e forma enquanto maneira de experimentar essa vida de modo saudável. $\mathrm{O}$ caminho percorrido para a estratificação da vida como fato biológico e histórico ampara-se em estratégias biopolíticas, em que a saúde é algo que se encontra no corpo vivido; ou seja, criamse jogos políticos de controle da vida, biopolíticas, por meio de enunciados do campo da saúde. Os jogos políticos com foco de investimentos tecnocientíficos 
se estabelecem entre as relações de produção de conhecimento sobre a vida, sobre o homem como um ser que vive, que fala e que trabalha, bem como sobre as populações-comunidades. Viver é ter que ser saudável, sendo que ter saúde é uma questão de postura de vida, e o indivíduo que não busca estratégias para se tornar mais saudável entra na categoria dos anormais.

$\mathrm{O}$ poder investe não exatamente na vida, mas nas formas de vida. Entretanto, esse poder ampara-se na vida e seus investimentos recaem sobre tornar esse fato uma forma de vida saudável, consumida enquanto mercadoria, pois as biotecnologias que maximizam a saúde e a vida são artefatos e dispositivos de consumo. A vida saudável produzida pelas ciências contemporâneas forja formas de relação do sujeito consigo mesmo por meio do corpo, de um corpo orgânico mirado na relação com a doença, com a saúde, enfim, com as farmacoterapias que medicalizam qualquer possibilidade de vida.

No campo da saúde, encontramos esse território existencial citado desde o início - as biotecnologias na relação que estabelecem com a vida e as tecnologias de si. Elas voltam-se para a vida como fato biológico, tornando-se condições de existência, condições estas que são objetivadas biologicamente; condições que buscam forjar formas que transcendam uma condição: a biologia suplantando os limites do orgânico e da finitude. Ser saudável é não envelhecer, é não se restringir aos limites físicos do corpo, pois esse corpo, quando saudável pela manipulação biotecnológica, não tem mais limites. São estratégias de poder que incitam a idéia de que o indivíduo tem controle absoluto sobre o próprio corpo, a própria vida. Maximizar a vida engendra-se na experiência produzida no próprio campo da ciência, da finitude da vida.

$\mathrm{O}$ poder que investe na vida a esquadrinha e otimiza; localiza-a em regiões cada vez menores, em uma interioridade: "o indivíduo condenado a uma busca interminável de um ponto fixo em si mesmo, uma vez que não pode mais encontrá-lo fora de si - todas as relações com os outros sendo em última análise estações na estrada pela qual o eu chega a si mesmo" (Bauman, 1999, p. 211). Ser saudável, quando correlacionado com as biotecnologias, individualiza a existência ao reforçar a noção de que o sujeito tem que ser empreendedor de si, responsável por si. A iminência de o humano tornar-se um ciborgue cria a necessidade de se inscrever em outra dimensão existencial que o diferencie da máquina, assim como a razão nos diferencia do mundo animal. Desse modo, a saúde torna-se um dispositivo que humaniza os ciborgues, que humaniza a vida; ou seja, somos máquinas, somos ciborgues, mas temos saúde, e a saúde é um bem do ser vivo, e não da máquina. Humanos e nãohumanos são misturados, hibridizados; o paradoxo encontra-se nessa relação em que comprar saúde por meio de biotecnologias é uma estratégia de humanizar a existência.

As tecnologias da vida constituem comunidades (ciborgues) por meio de estratégias, discursos que capturam os sujeitos. Ao serem alistados por estratégias e discursos, os sujeitos passam a constituir esses próprios campos de saber, de verdade sobre como viver, como trabalhar, como cuidar de si mesmo. Ao serem incitados, sustêm aquilo que os recruta. As biopolíticas são jogos de verdade que, ao objetivarem no campo da saúde as biotecnologias, criam o modo como deve ser o sujeito, as condições a que está submetido, o seu status, a posição que deve ocupar para tornar-se um sujeito legítimo; isto é, as tecnologias da vida produzem formas de subjetivação.

Entretanto, as biotecnologias não são jogos impostos de fora para os sujeitos. Ambas as estratégias abrem um campo de experiência em que sujeito (ciborgues) e objeto (biotecnologias) são constituídos em certas condições simultâneas, mas não param de se modificar e de modificar esse campo de experiência (Foucault, 2004).O campo de experiência faz-se por meio de práticas, de formas de agir e de pensar que constituem a possibilidade de inteligibilidade do sujeito e do objeto. Esse campo constitui-se de formas particulares e diversas de governo dos indivíduos que determinam distintos modos de objetivação do sujeito e diferentes modos de subjetivação. $\mathrm{O}$ que se quer deixar claro é que as biotecnologias no campo da saúde são estratégias de governo que, ao mesmo tempo em que são forjadas como objetos no campo da saúde, por meio das práticas que as constituem como objetos, criam as condições de visibilidade e dizibilidade dos sujeitos que produzem. Não se trata, então, de uma história das idéias do que seriam as biotecnologias, mas de um pensamento enquanto ele busca tornar-se técnico (Rose, 2001).

As biotecnologias são formas de governo, controlam a possibilidade de finitude da vida, tornam a vida e a saúde um artefato que deve ser modificado, relacionam a vida com a não-vida para minimizar os efeitos da própria vida, não por seus princípios doutrinários e organizativos, mas pela intervenção técnica na vida, pela imposição da longevidade e da beleza, pela possibilidade de o sujeito manipular e transformar o próprio corpo e a própria vida por meio das tecnociências. Não obstante, é importante ter presente que são as tecnociências que estabelecem as 
normas de como deve ser esse corpo, essa vida, essa saúde, o que deve ser modificado, como deve ser modificado.

\section{REFERÊNCIAS}

Bauman, Z. (1999). Modernidade e Ambivalência. Rio de Janeiro: Jorge Zahar.

Bauman, Z. (2001). Modernidade líquida. Rio de Janeiro: Jorge Zahar.

Blanchot, M. (2001). A conversa infinita. São Paulo: Escuta.

Deleuze, G. (1992). Conversações. Rio de Janeiro: 34.

Foucault, M. (1987). Vigiar e Punir. Petrópolis: Vozes.

Foucault, M. (1990). Tecnologias del yo. En M. Foucault, Tecnologías del yo y otros textos afines (pp. 45-94). Barcelona: Paidós.

Foucault, M. (1995). O sujeito e o poder. Em H. Dreyfus \& P. Rabinow, Michel Foucault, uma trajetória filosófica: para além do estruturalismo e da hermenêutica (pp. 231-249). Rio de Janeiro: Forense.

Foucault, M. (1996). A ordem do discurso. São Paulo: Loyola.

Foucault, M. (1999). História da Sexualidade I: a vontade de saber. Rio de Janeiro: Graal.
Foucault, M. (2000). Arqueologia do Saber. Rio de Janeiro: Forense Universitária.

Foucault, M. (2004). Ética, sexualidade, política. Rio de Janeiro: Forense Universitária.

Levy, T. (2003). A experiência do fora: Blanchot, Foucault, Deleuze. Rio de Janeiro: Relume Dumará.

Menconi, D. \& Pinho C. (2004, 4 de agosto). Século 21: ciência, tecnologia e meio ambiente. Istoé, 1817, 91-93.

Nietzsche, F. (1998). Genealogia da moral: uma polêmica. São Paulo: Companhia das Letras.

Oliveira, L. (2004). Nanotecnologia assemelha homens $e$ máquinas. Disponível em: <http://www.comciencia.br/ entrevistas/ nanotecnologia/oliveira.htm>. (Acesso em 29/07/2004)

Pelbart, P. (2000). A vertigem por um fio. São Paulo: Iluminuras.

Rose, N. (2001). Como se deve fazer a história do Eu?. Educação \& Realidade, 26(1), 33-57.

Sibila, P. (2002). O homem pós-orgânico: corpo, subjetividade e tecnologias digitais. Rio de Janeiro: Relume Dumará.

Recebido em 08/08/2005 Aceito em 05/07/2006

Endereço para correspondência: Neuza Guareschi. Av. Nilópolis, 375/401, CEP 90460-050, Porto Alegre-RS.

E-mail: nmguares@pucrs.br 